\title{
Electrochemical Bromide Sensing with a Halogen Bonding [2]Rotaxane
}

\author{
Jason Y. C. Lim ${ }^{[a]}$ and Paul D. Beer ${ }^{*[a]}$
}

\begin{abstract}
The selective electrochemical sensing of heavy halides such as bromide over more charge-dense counterparts like chloride using mechanically-interlocked structures remains a formidable challenge. Using the active-metal templation methodology, the first redox-active ferrocene-appended rotaxane containing an all-halogen bonding anion binding cavity was synthesised. ${ }^{1} \mathrm{H}$ NMR binding studies in aqueous-organic solvent media demonstrated a marked recognition bias for heavy halides, facilitating the selective redox sensing of bromide over chloride to be demonstrated for the very first time with an interlocked host molecule.
\end{abstract}

\section{Introduction}

Bromide is pervasive in the biosphere and is present in natural waters typically at concentrations of tens of $\mathrm{mg} / \mathrm{L} .{ }^{[1]}$ Although its physiological roles are currently not as well-understood as those for chloride ${ }^{[2-4]}$ and iodide, ${ }^{[5,6]}$ bromide has been shown to be essential for tissue development in humans, ${ }^{[7]}$ while excessive quantities can be toxic $(>12 \mathrm{mM}),{ }^{[8]}$ and delay postnatal growth and brain development. ${ }^{[9]}$ In addition, the presence of excessive quantities of bromide in water can affect the efficacy of water treatment processes, ${ }^{[10]}$ and even react with disinfectants to produce toxic brominated by-products. ${ }^{[11]}$ The need to detect the presence of bromide and monitor its concentration has spurred the development of numerous abiotic halide sensors. ${ }^{[12-16]}$ Owing to its intermediate size and hydration energy between chloride and iodide, ${ }^{[17]}$ selective binding and sensing of bromide is highly challenging and has only been achieved with a handful of receptors. ${ }^{[18-20]}$

Electrochemical anion sensors are host molecules capable of displaying a detectable redox signal output upon anion complexation, and are highly desirable due to their inherent selectivity and potential integration into devices. ${ }^{[21]}$ While numerous redox-active functionalities have been employed, ferrocene remains the most popular due to its stability, favourable voltammetric properties and ease of chemical functionalisation. ${ }^{[22-24]}$ Incorporating ferrocene into mechanicallyinterlocked host molecules which contain highly-preorganised three-dimensional binding cavities of complementary geometric shape and size for chloride, enabled the selective redox sensing of chloride in dry organic solvents to be demonstrated. ${ }^{[25-29]}$ Nonetheless, the use of this class of molecules for redox sensing of heavier halides such as bromide ${ }^{[30]}$ in competitive aqueous solvent media remains unrealised. For this purpose, we

[a] J. Y. C. Lim and Prof. P. D. Beer Department of Chemistry University of Oxford

Chemistry Research Laboratory, Mansfield Road, Oxford, OX1 3TA

E-mail: paul.beer@chem.ox.ac.uk

URL: http://beer.chem.ox.ac.uk/

Supporting information for this article is given via a link at the end of the document. envisaged that the utilisation of halogen bonding (XB), the supramolecular interaction between electron-deficient heavy halogen donor atoms and Lewis bases such as anions, ${ }^{[31,32]}$ in our rotaxane host design (Figure 1) would be ideal. Other than the steric bulk of the halogen bond donor iodine atom and its stringent linearity, which enforces greater geometric control and complementarity for guest binding, its preference for binding 'softer' halide anions under aqueous conditions contrasts with hydrogen bonding (HB) host analogues. ${ }^{[33]}$ Furthermore, the significant covalent character of XB-anion interactions ${ }^{[34,35]}$ can amplify the sensitivity of anion sensing by facilitating the throughspace electronic communication between the redox-active moiety and the bound anion. ${ }^{[36-38]}$ Taking these factors into consideration, we describe herein the synthesis of the first redox-active [2]rotaxane containing an all-XB anion binding cavity, as well as its unprecedented selective XB-mediated electrochemical sensing of bromide in organic solvents containing as much as $10 \%$ water by volume.

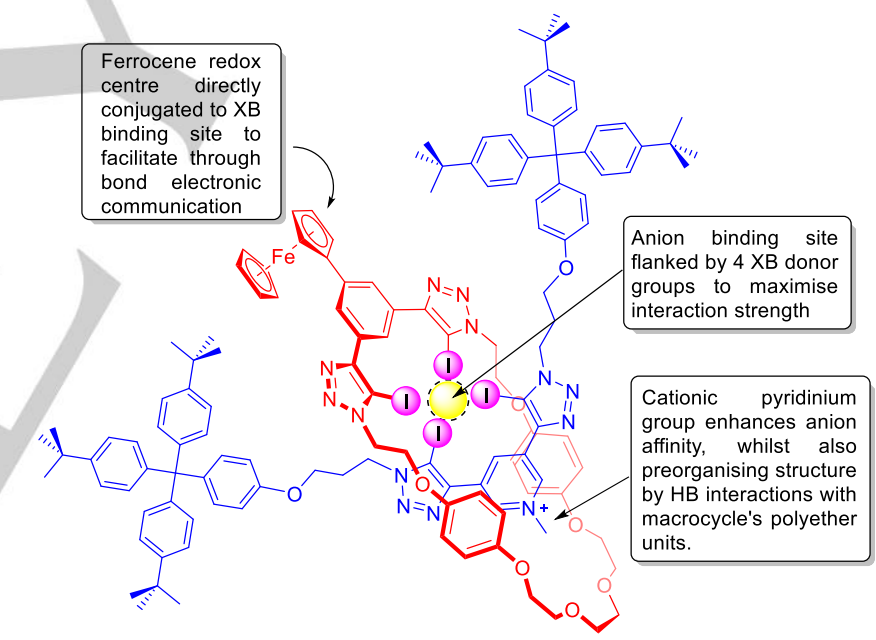

Figure 1. Structure and design features of the target all-XB redox-active [2]rotaxane 1 for selective bromide sensing.

\section{Results and Discussion}

\section{Synthesis of Halogen Bonding [2]Rotaxane}

The target [2]rotaxanes were synthesized by the active metal templation (AMT) protocol, where endotopic coordination of the catalytically-active metal cation within the cavity of a macrocycle forms a mechanical covalent bond between axle precursors through the cavity of the macrocycle. ${ }^{[39,40]}$ The retrosynthetic strategy towards the target monocationic rotaxane is shown in Scheme 1A. 


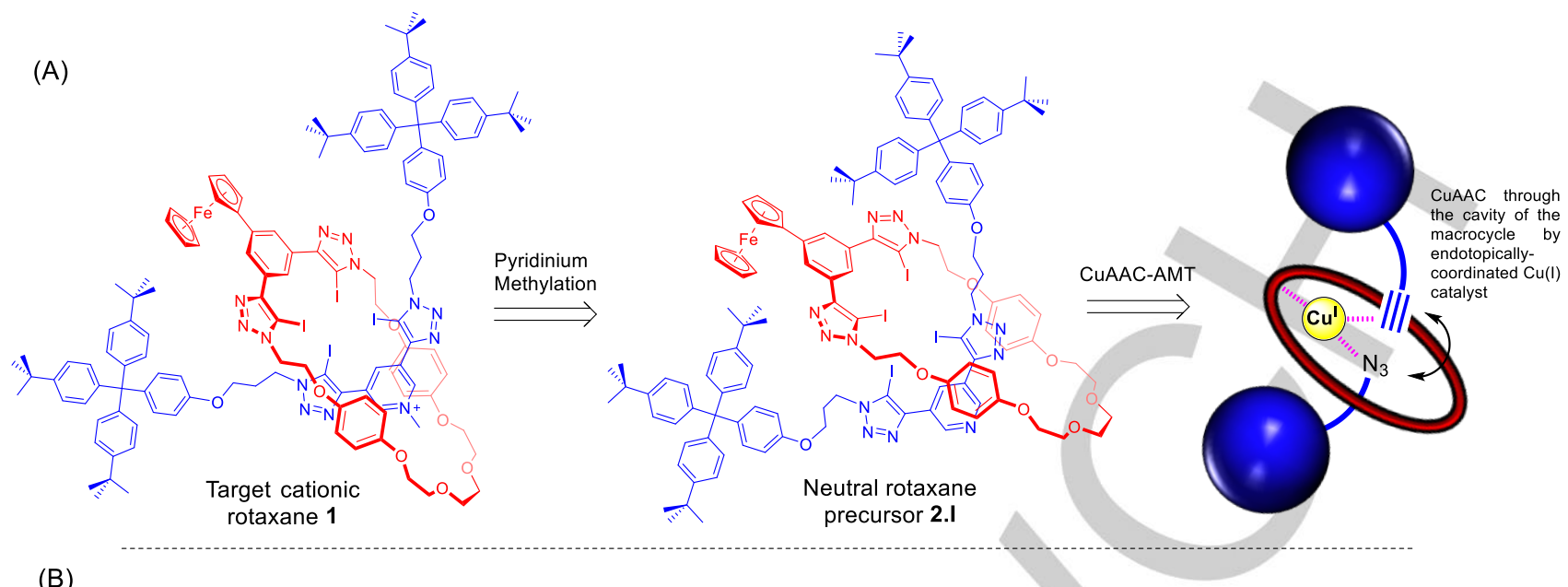

(B)

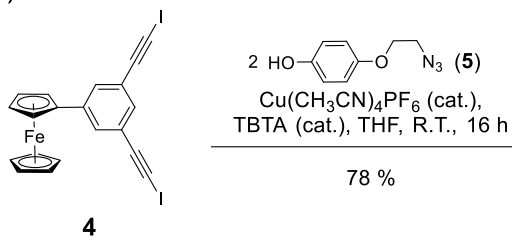

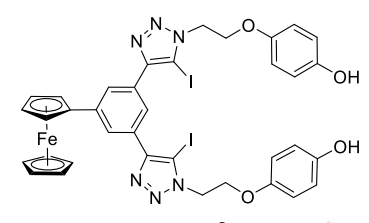

6

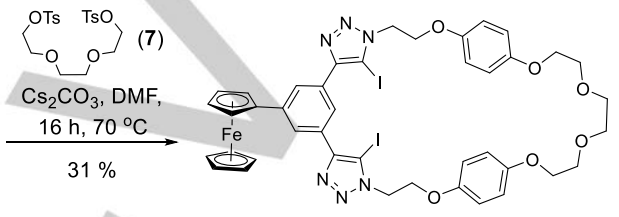

Macrocycle 3.1

(C)

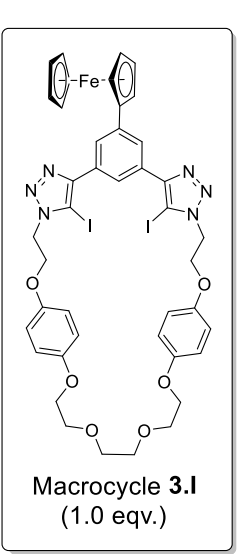

Approach 1
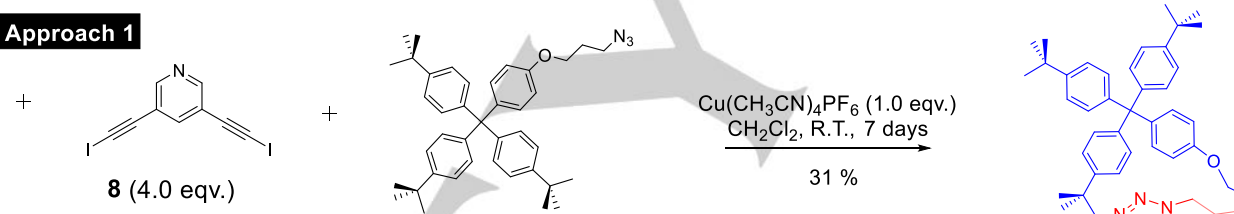

Approach 2

9 (8.0 eqv.)
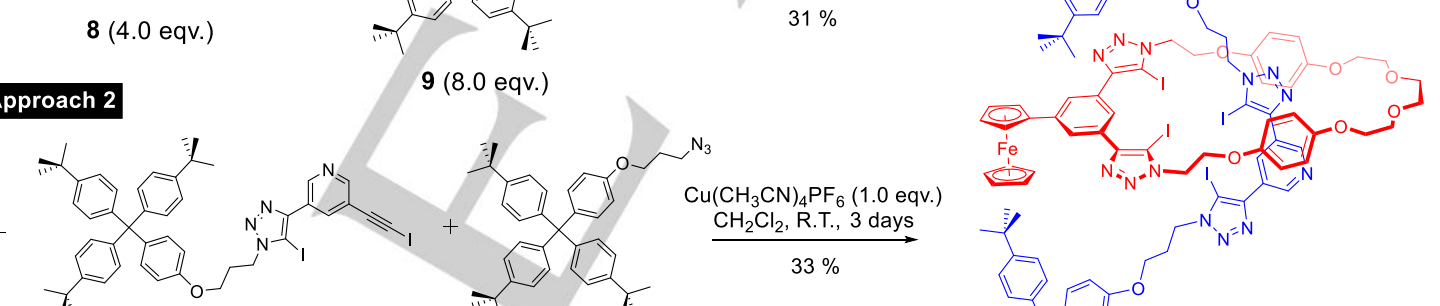

10 (4.0 eqv.)

9 (4.0 eqv.)

$33 \%$
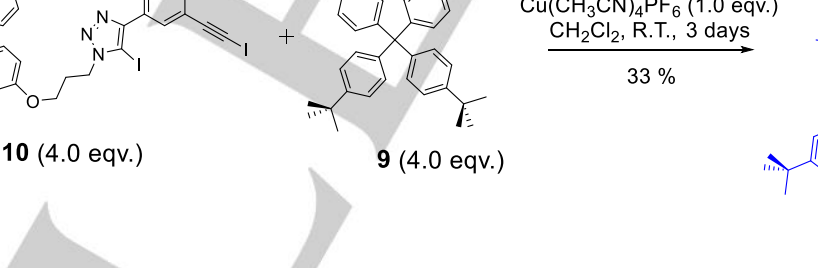

Scheme 1. (A) Retrosynthesis of target rotaxane 1; (B) Synthesis of ferrocene-appended XB macrocycle 3.I; (C) Synthesis of neutral all-XB rotaxane 2.I.

As shown in Scheme $1 \mathrm{~B}$, the multistep synthesis of ferrocene-appended XB macrocycle 3.1 was achieved by first reacting bis(iodoalkyne) 4 and two equivalents of azide 5 via a copper(I)-catalysed azide-alkyne cycloaddition (CuAAC) protocol to form the bis-phenol precursor 6 . Subsequent ring-closing was accomplished by Williamson ether synthesis ${ }^{[41]}$ between 6 and bis-tosylate 7 under basic conditions to afford macrocycle $\mathbf{3 . I}$ in $31 \%$ isolated yield. A qualitative ${ }^{1} \mathrm{H}$ NMR titration experiment of macrocycle 1 with $\left[\mathrm{Cu}\left(\mathrm{CH}_{3} \mathrm{CN}\right)_{4}\right] \mathrm{PF}_{6}$ in $\mathrm{CD}_{2} \mathrm{Cl}_{2}$ confirmed that the macrocycle was binding $\mathrm{Cu}(\mathrm{I})$ via the Lewis basic nitrogen atoms of the iodotriazole groups (see Fig. S2-1, Supporting Information), a prerequisite for 3.1 to be amenable towards CuAAC-AMT rotaxane synthesis. Indeed, a macrocycle containing the 1,3bis(iodotriazole)benzene motif has been used to synthesise a family of XB rotaxanes by CuAAC-AMT, demonstrating that the benzene-iodotriazoles are conformationally-flexible enough to allow the $\mathrm{Cu}(\mathrm{I})$ to be coordinated in an endotopic fashion facing the interior of the macrocycle's cavity. ${ }^{[41]}$

Thereafter, the CuAAC-AMT synthesis of the neutral rotaxane 2.I was attempted using two approaches (Scheme 1C). In the first approach, rotaxane 2 .I was synthesised by reacting 1.0 equivalent of macrocycle 3.1 and equimolar quantities of $\left[\mathrm{Cu}\left(\mathrm{CH}_{3} \mathrm{CN}\right)_{4}\right] \mathrm{PF}_{6}$ with 4.0 equivalents of pyridine-3,5bis(iodoalkyne) 8 with 8.0 equivalents of azide 9 under a $\mathrm{N}_{2}$ atmosphere with dry degassed $\mathrm{CH}_{2} \mathrm{Cl}_{2}$. Under these conditions, complete consumption of the axle precursors was seen after 7 days, whereupon rotaxane 2.I could be detected by ESI-MS analysis of the crude reaction mixture $\left(\mathrm{m} / \mathrm{z}=2588.7[\mathrm{M}+\mathrm{H}]^{+}\right)$, and subsequently isolated by preparatory thin layer chromatography (TLC) in $31 \%$ yield. Interestingly, monitoring the progress of the 
reaction via TLC and ESI-MS revealed that the singly-clicked pyridine-iodoalkyne $10\left(\mathrm{~m} / z=967.2[\mathrm{M}+\mathrm{H}]^{+}\right)$was formed as an intermediate in the rotaxane synthesis (Figure S1-1, Supporting Information). Hypothesising that intermediate 11, rather than pyridine-3,5-bis(iodoalkyne) 9.I, was directly involved in rotaxane formation, the equimolar macrocycle 3.I- $\left[\mathrm{Cu}\left(\mathrm{CH}_{3} \mathrm{CN}\right)_{4}\right] \mathrm{PF}_{6}$ mixture was reacted with 10 (4.0 equivalents) and azide 9 (4.0 equivalents) to produce the same rotaxane in a similar yield of $33 \%$ after 3 days under identical reaction conditions (Approach 2 in Scheme 1C).

Having formed the target all-XB neutral rotaxane 2.I, methylation of the axle pyridine moiety was achieved by stirring a $\mathrm{CH}_{2} \mathrm{Cl}_{2}$ solution of the rotaxane with excess iodomethane overnight (Scheme 2). Anion exchange to the non-coordinating hexafluorophosphate $\left(\mathrm{PF}_{6}^{-}\right)$salt was achieved by repeatedly washing a chloroform solution of the rotaxane with $0.1 \mathrm{M} \mathrm{NH}_{4} \mathrm{PF}_{6}$ to afford the target rotaxane $\mathbf{1}$ in $76 \%$ overall yield (see Experimental section). A comparison of the ${ }^{1} \mathrm{H}$ NMR of rotaxane 1 before and after axle methylation reveals the structural changes brought about by the reaction. As seen from Figure $2 \mathrm{~A}$, although the formation of neutral rotaxane $\mathbf{2 . I}$ gave rise to significant upfield shifts of the hydroquinone proton signals compared with free macrocycle 3.I, further upfield shifts were seen for monocationic rotaxane 1 , likely due to enhanced donor-acceptor aromatic п-п stacking interactions with the more electron-deficient pyridine-3,5bis(iodotriazolium) functionality on the axle. Furthermore, these resonances were split to a greater extent for rotaxane 1 relative to 2.I, suggesting a greater degree of rotaxane rigidification due to possible HB interactions of the axle pyridinium methyl group with the macrocycle polyether segment- the latter supported by downfield shifts of the macrocycle component's polyether ${ }^{1} \mathrm{H}$ NMR signals. At the same time, this results in a notable upfield shift of $\mathrm{H}_{d}$ on the macrocycle component and downfield movement of axle $\mathrm{H}_{3}$. Indeed, 2D ROESY characterisation of rotaxane 1 (Figure 2B) shows strong through-space interactions between the hydroquinone protons and those on the axle's central pyridinium group $\left(\mathrm{H}_{1}\right.$ and $\left.\mathrm{H}_{2}\right)$, as well a notable cross-peak seen between the axle's proton $\mathrm{H}_{2}$ and the macrocycle polyether region. Together, these show that the macrocycle is predominantly residing over the central portion of the axle to form a well-defined binding cavity containing four convergent $\mathrm{XB}$ donor groups.

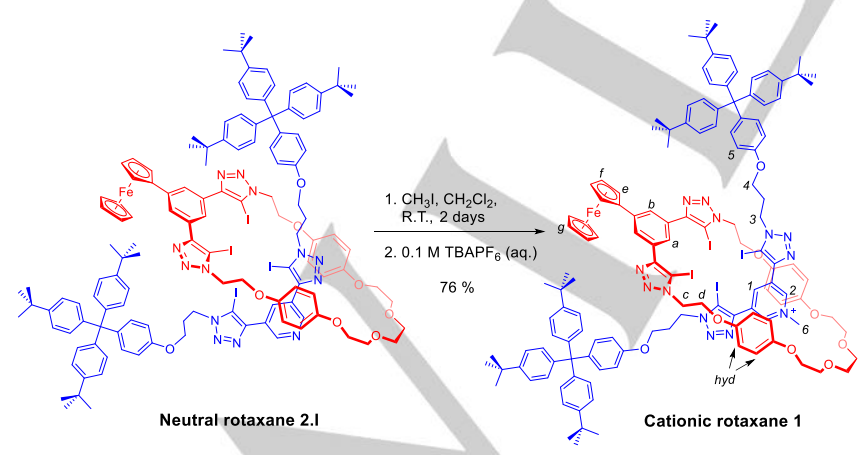

Scheme 2. Synthesis of monocationic rotaxane 1.

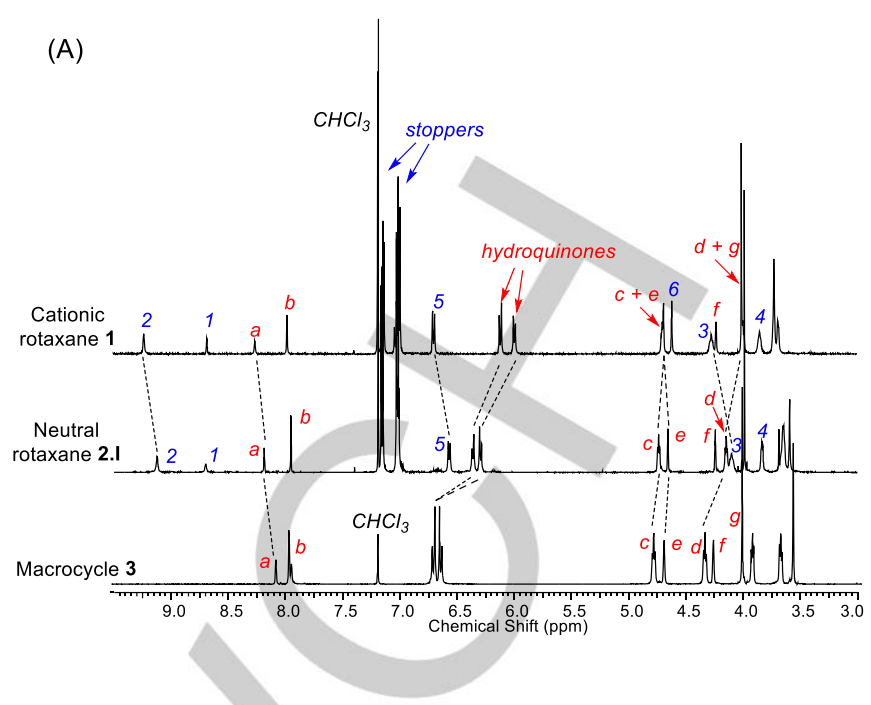

(B)

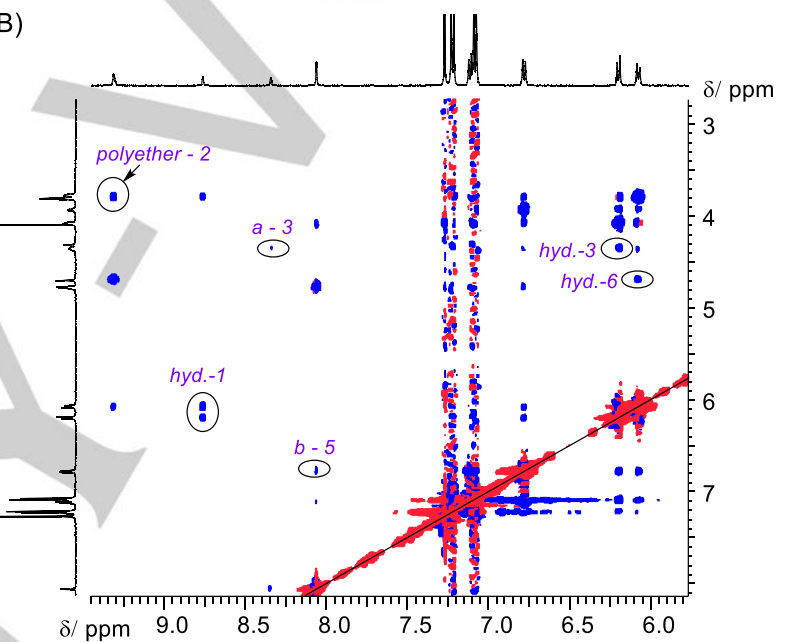

Figure 2. (A) Stacked partial ${ }^{1} \mathrm{H}$ NMR spectra of rotaxane 1, 2.1 and free macrocycle $\mathbf{3}$ in $\mathrm{CDCl}_{3}$; (B) 2D ROESY spectra of cationic rotaxane $\mathbf{1}$ in $\mathrm{CDCl}_{3}$ with cross peaks between the axle and macrocycle components circled. Proton assignments for rotaxane $\mathbf{1}$ follow those in Scheme 2.

\section{Anion Binding Studies}

Anion binding studies were performed by ${ }^{1} \mathrm{H}$ NMR titration experiments by adding increasing quantities of anions $\left(\mathrm{Cl}^{-}, \mathrm{Br}^{-}, \mathrm{I}^{-}\right.$, $\mathrm{SCN}^{-}$and $\mathrm{SO}_{4}{ }^{2-}$ ), as their tetrabutylammonium (TBA) salts, to a solution of the rotaxane in the competitive aqueous solvent mixture of $\mathrm{CD}_{3} \mathrm{CN} / \mathrm{d}_{6}$-acetone/ $\mathrm{D}_{2} \mathrm{O} 45: 45: 10 \mathrm{v} / \mathrm{v} / \mathrm{v}$. The addition of all halides gave downfield shifts of the proton resonances surrounding the rotaxane cavity $\left(\mathrm{H}_{1}\right.$ and $\left.\mathrm{H}_{\mathrm{a}}\right)$ (Figure $3 \mathrm{~A}$ ), albeit with different magnitudes (Figure $3 \mathrm{~B}$ ), showing that they were binding in the binding pocket flanked by four $\mathrm{XB}$ donor groups. Due to the steric bulk of the XB-donor iodine atoms surrounding the anion binding cavity, it is likely that the anions were bound above the plane of the macrocycle component, which may account for the downfield signal shifts observed for axle proton $\mathrm{H}_{3}$ as a result of weak hydrogen bonding with the anion bound in close proximity. In addition, halide binding elicited shifts for $\mathrm{H}_{2}, \mathrm{H}_{4}$ and $\mathrm{H}_{5}$ on the axle component, as well as $\mathrm{H}_{d}$ and $\mathrm{H}_{e}$ on the macrocycle, with the larger halides bringing about greater shifts (see Figures S3-2 to S3-4, Supporting Information). This suggested that a greater degree of rotaxane conformational 
change accompanied the binding of heavier halides, possibly as the axle and macrocycle components adjust their relative positions to accommodate the anion and to maximise the number of convergent linear XB interactions.

Compared with the spherical halides, the linear $\mathrm{SCN}^{-}$anion elicited different proton signal perturbations upon binding with rotaxane 1 (Figure S3-5, Supporting Information). While modest downfield shifts were seen for internal pyridinium proton $\mathrm{H}_{1}$ 's resonance, the most pronounced (upfield) perturbations were seen for the axle protons $\mathrm{H}_{3}, \mathrm{H}_{4}$ and $\mathrm{H}_{5}$, whilst no shifts were observed for the axle pyridinium methyl protons $\mathrm{H}_{6}$. This suggested that although $\mathrm{XB}$ interactions were still primarily driving $\mathrm{SCN}^{-}$binding in the vicinity of the rotaxane cavity, the anion was too large to fit completely within it. For $\mathrm{SO}_{4}{ }^{2-}$ (Figure S3-6, Supporting Information), very small shifts of all rotaxane proton resonances were seen, with the internal pyridinium proton $\mathrm{H}_{1}$ only moving downfield by +0.03 ppm after addition of 10.0 equivalents of the oxoanion. Despite being capable of the strongest electrostatic attractions with the rotaxane, these results indicated that $\mathrm{SO}_{4}{ }^{2-}$ was interacting very weakly with rotaxane 1 , which is probably a consequence of the anion's strong hydration in the aqueous solvent mixture and large size preventing access to the binding cavity. Monitoring the shifts of internal pyridinium proton $\mathrm{H}_{1}$ during the course of the titration experiments and fitting the data to a 1:1 stoichiometric host-guest binding model using WinEQNMR2[42] enabled anion association constants to be determined (Table 1).

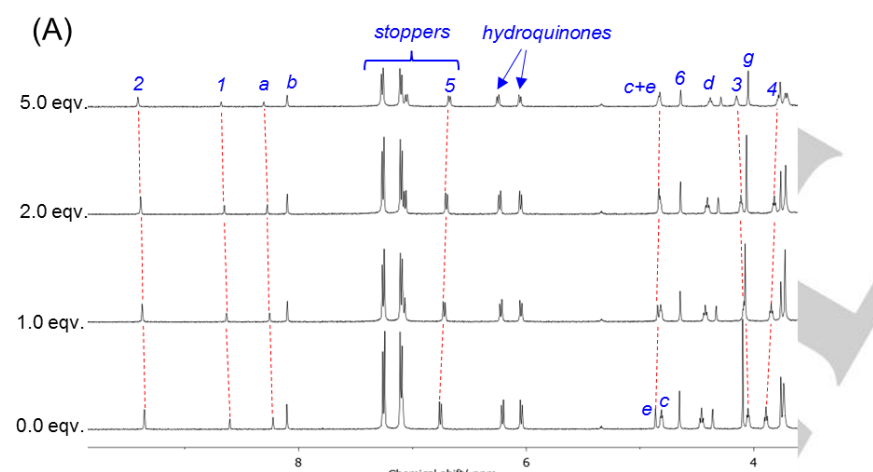

(B)

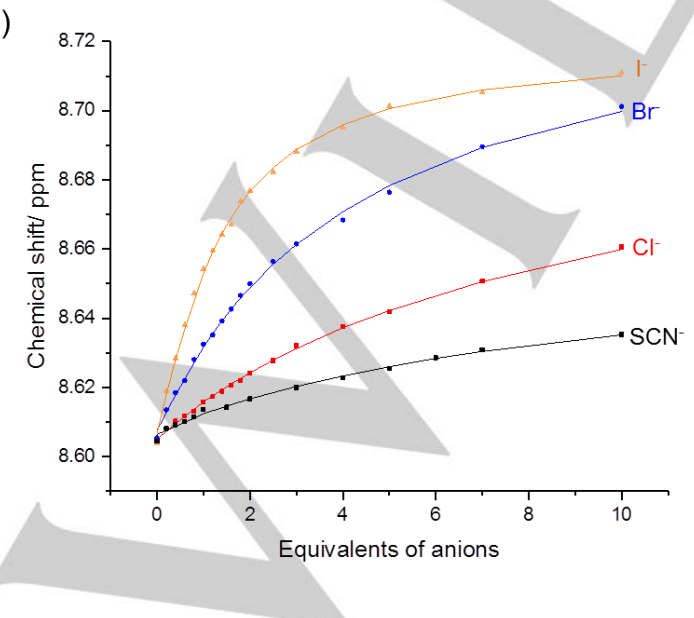

Figure 3. (A) Partial ${ }^{1} \mathrm{H}$ NMR spectra of rotaxane 1 in the presence of $0.0,1.0$ 2.0 and 5.0 equivalents of $\mathrm{TBABr}$; (B) Binding isotherms of rotaxane 1 with various anions, showing the changes in chemical shift of internal pyridinium proton $\mathrm{H}_{1}$ with increasing quantities of anions added ([rotaxane 1] $=1.0 \mathrm{mM}$ $\mathrm{CD}_{3} \mathrm{CN} / \mathrm{d}_{6}$-acetone/ $\mathrm{D}_{2} \mathrm{O}$ 45:45:10 $v / v / v, T=298 \mathrm{~K}$ ). Proton labels follow those in Scheme 3.

Table 1. Anion association constants $\left(K_{\mathrm{a}} / \mathrm{M}^{-1}\right)$ of rotaxane . $^{[\mathrm{a}]}$

\begin{tabular}{ll}
\hline Anion & $K_{\mathrm{a}} / \mathrm{M}^{-1}$ \\
\hline $\mathrm{Cl}^{-}$ & $101(4)$ \\
$\mathrm{Br}$ & $340(5)$ \\
$\mathrm{I}^{-}$ & $1125(5)$ \\
$\mathrm{SCN}^{-}$ & $102(8)$ \\
$\mathrm{SO}_{4}{ }^{2-}$ & $-[\mathrm{b}]$ \\
\hline
\end{tabular}

[a] $K_{\mathrm{a}}$ values determined by WinEQNMR2 software ${ }^{[42]}$ by monitoring axle pyridinium proton $\mathrm{H}_{1}$; errors $( \pm$ ) in parentheses ([Rotaxane 1] $=1.0 \mathrm{mM}$; $\mathrm{CD}_{3} \mathrm{CN} / \mathrm{d}_{6}$-acetone/ $\mathrm{D}_{2} \mathrm{O}$ 45:45:10 $v / v, T=298 \mathrm{~K}$ ). [b] Binding too weak to be accurately quantified.

Amongst the halide anions, a clear Hofmeister binding preference for $\mathrm{I}^{-}$can be seen, with the $K_{\mathrm{a}}$ value for $\mathrm{I}^{-}$more than an

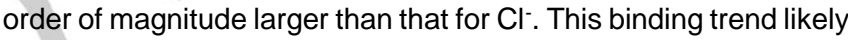
arises as the heavier halides are less strongly hydrated, energetically favouring dehydration accompanying anion binding in the hydrophobic all-XB binding cavity of rotaxane 1 . However, considering that $\mathrm{SCN}^{-}$is even more poorly hydrated than $\mathrm{I}^{-[17]}$ and thus would be expected to be most strongly bound based on ease of dehydration alone, its much smaller $\mathrm{K}_{\mathrm{a}}$ value compared with $\mathrm{I}$ further highlights the critical importance of geometric and size complementarity for anion recognition by rotaxane 1 , with the spherical halides bound preferentially over other anion geometries.

\section{Electrochemical Anion Sensing}

The redox anion sensing properties of rotaxane 1 towards $\mathrm{Cl}^{-}, \mathrm{Br}$ and $\mathrm{SCN}^{-}$were probed using square-wave voltammetry in acetone/ $\mathrm{CH}_{3} \mathrm{CN} / \mathrm{H}_{2} \mathrm{O}$ 45:45:10 $\mathrm{v} / \mathrm{v} / \mathrm{V}$ mixtures containing $0.1 \mathrm{M}$ TBAPF $_{6}$ as supporting electrolyte. ${ }^{[43]}$ A standard three electrode cell, comprising of a glassy carbon working electrode, a Pt wire counter electrode and $\mathrm{a} \mathrm{Ag} / \mathrm{AgNO}_{3}$ non-aqueous reference electrode ${ }^{[44]}$ was used.

Rotaxane 1 displays redox quasi-reversibility in dry acetone/ $\mathrm{CH}_{3} \mathrm{CN}$ 1:1 $\mathrm{v} / \mathrm{v}$, as well as in acetone/ $\mathrm{CH}_{3} \mathrm{CN} / \mathrm{H}_{2} \mathrm{O}$ 45:45:10 $\mathrm{v} / \mathrm{V}$ (see Section S4.1, Supporting Information). Interestingly, cationic rotaxane 1 and free neutral macrocycle 3.I showed almost identical ferrocene/ ferrocenium $\left(\mathrm{Fc} / \mathrm{Fc}^{+}\right)$oxidation potentials (see Table 2), which is contrary to the expectation that the oxidation of a cationic receptor would be thermodynamically less favoured. In the presence of $10 \%$ water by volume, a consistent cathodic shift of the $E_{1 / 2}$ values were seen for both rotaxane 1 and macrocycle 3.I, which may arise from the presence of water solvating and hence thermodynamically stabilising the charged ferrocenium species following oxidation. Curiously, the magnitude of $\Delta E_{1 / 2}$ of rotaxane 1 was smaller than that for macrocycle 3.I. This may be rationalised considering that upon oxidation, the charge of macrocycle $3 . I$ increases from 0 to +1 , while that of the already-cationic rotaxane 1 increases from +1 to +2 . The resulting 
greater changes to the hydration of macrocycle 3.I upon oxidation from a neutral species is likely to bring about a more pronounced hydration-induced oxidised receptor stabilisation.

Table 2. Redox potentials $\left(E_{1 / 2} / \mathrm{mV}\right)$ of the $\mathrm{Fc} / \mathrm{Fc}^{+}$couples of macrocycle 3.I and rotaxane $\mathbf{1}$ in wet and dry solvents. ${ }^{[a]}$

\begin{tabular}{lccc}
\hline Host & $\begin{array}{c}\text { Acetone/ } \\
\mathrm{CH}_{3} \mathrm{CN} \mathrm{1:1}\end{array}$ & $\begin{array}{c}\text { Acetone } / \mathrm{CH}_{3} \mathrm{CN} / \mathrm{H}_{2} \mathrm{O} \\
45: 45: 10\end{array}$ & $\Delta E_{1 / 2}{ }^{[\mathrm{b}]}$ \\
\hline Macrocycle 3.I & 218 & 184 & -34 \\
Rotaxane 1 & 224 & 212 & -12 \\
\hline
\end{tabular}

[a] Values reported relative to the $\mathrm{Ag} / \mathrm{AgNO}_{3}$ reference electrode; glassy carbon working electrode, $\mathrm{Pt}$ wire auxiliary electrode, electrolyte: $0.1 \mathrm{M}$ TBAPF $_{6}$ in the appropriate solvent, $T=293 \mathrm{~K}$. [b] $\Delta E_{1 / 2}=E_{1 / 2 \text { (wet) }}-E_{1 / 2 \text { (dry). }}$.

In the competitive electrolyte solution of acetone/ $\mathrm{CH}_{3} \mathrm{CN}$ / $\mathrm{H}_{2} \mathrm{O} 45: 45: 10 \mathrm{v} / \mathrm{v} / \mathrm{V}$, the presence of 20 equivalents of $\mathrm{Cl}^{-}$gave a negligible cathodic shift $(<5 \mathrm{mV})$, whilst a considerably augmented redox response was observed for $\mathrm{Br}^{-}$(Table 3). Even with a greater extent of receptor saturation in the presence of large excesses of anions (50 and 150 equivalents), $\mathrm{Br}$ consistently elicited more pronounced cathodic shifts than $\mathrm{Cl}^{-}$ (Table 3 and Figure 4). ${ }^{[45]}$ It is especially notable that a large excess of $\mathrm{Cl}^{-}$(50 equivalents) gave no detectable pertubations of the $\mathrm{Fc} / \mathrm{Fc}^{+}$redox couple of macrocycle $3 . \mathrm{I}$ in acetone/ $\mathrm{CH}_{3} \mathrm{CN} /$ $\mathrm{H}_{2} \mathrm{O}$ 45:45:10 $\mathrm{V} / \mathrm{V} / \mathrm{V}$ (Figure S4-7, Supporting Information), highlighting the augmented sensory capabilities of rotaxane 1 even for highly-hydrated anions.

The greater electrochemical response to $\mathrm{Br}^{-}$over $\mathrm{Cl}^{-}$may be attributed to numerous contributing factors. In the presence of 20 equivalents of anions, rotaxane $\mathbf{1}$ was not yet completely saturated, and therefore the greater cathodic shift seen for $\mathrm{Br}^{-}$is partly reflective of the greater proportion of bound rotaxane- $\mathrm{Br}$ complex present. Upon almost complete rotaxane host saturation with a 150-fold excess of anions, the magnitude of the redox response becomes reflective of the extent at which the anion guest is able to interact with and stabilise the oxidised ferrocenium form of the rotaxane. ${ }^{[21]}$ With its lower hydration energy, $\mathrm{Br}^{-}$is potentially able to bind more strongly than $\mathrm{Cl}^{-}$to the more electron-deficient rotaxane cavity upon oxidation, thermodynamically stabilising the oxidised form to a greater extent and concomitantly bringing about a larger magnitude of cathodic shift. Nonetheless, a significant redox response is also dependent upon the efficacy of electronic communication and coupling between the rotaxane binding cavity and the ferrocene unit. Although XB interactions appear to favour through-bond electronic communication ${ }^{[36]}$ owing to the pronounced covalency of the XB-halide interactions, ${ }^{[35]}$ the difference in location of binding between $\mathrm{Cl}^{-}$and $\mathrm{Br}$ may also influence the magnitude of response as well. Due to its larger ionic radius, $\mathrm{Br}^{-}$was likely bound strongly further above the plane of the macrocycle component of the rotaxane than $\mathrm{Cl}^{-}$, as evident from the more pronounced ${ }^{1} \mathrm{H}$ NMR signal perturbations of the rotaxane stopper aromatic proton $\mathrm{H}_{6}$ observed for the former anion (see Figures S3-2 and S3-3, Supporting Information). This may potentially bring the anion into closer spatial proximity to the pendant ferrocene unit on the exterior of the macrocycle, facilitating through-space redox communication. Notably, the exceptionally small redox response observed for $\mathrm{SCN}^{-}$may be attributed to its poor size and shape complementarity with the rotaxane's XB binding site (vide supra), as well as its lower charge density compared to the halides, preventing effective stabilisation of the oxidised ferrocenium moiety.

Table 3. Magnitudes of cathodic shifts $\left(\Delta E_{1 / 2} / \mathrm{mV}\right)$ of the $\mathrm{Fc} / \mathrm{Fc}^{+}$redox couple of rotaxane 1 in acetone/ $\mathrm{CH}_{3} \mathrm{CN} / \mathrm{H}_{2} \mathrm{O} 45: 45: 10$. [a]

\begin{tabular}{llll}
\hline \multirow{2}{*}{ Eqv. of anions } & \multicolumn{2}{l}{$\Delta E_{1 / 2} / \mathrm{mV}$} \\
\cline { 2 - 4 } & $\mathrm{Cl}^{-}$ & $\mathrm{Br}^{-}$ & $\mathrm{SCN}^{-}$ \\
\hline 20 & -2 & -10 & -1 \\
50 & -6 & -14 & -2 \\
150 & -11 & -21 & -4 \\
\hline
\end{tabular}

[a] Anions added as TBA salts, electrolyte: $0.1 \mathrm{M} \mathrm{TBAPF}_{6}$ in acetone/ $\mathrm{CH}_{3} \mathrm{CN}$ / $\mathrm{H}_{2} \mathrm{O}$ 45:45:10 $\mathrm{v} / \mathrm{v} / \mathrm{v}$; errors estimated at $\pm 5 \mathrm{mV}$; ([receptor] $=0.1 \mathrm{mM}, T=293$ $\mathrm{K})$

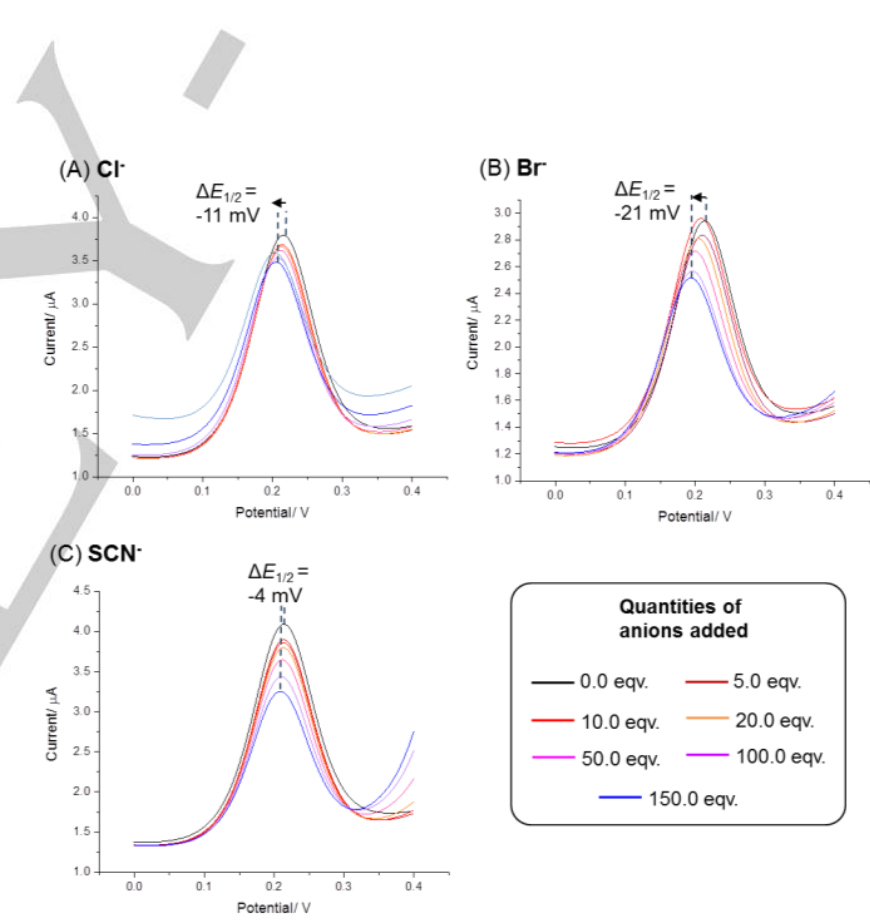

Figure 4. Square-wave voltagrams of rotaxane 1 in the presence of increasing quantities of $(\mathrm{A}) \mathrm{Cl}^{-}$; $(\mathrm{B}) \mathrm{Br}^{-}$and $(\mathrm{C}) \mathrm{SCN}^{-}$([rotaxane 1] $=0.1 \mathrm{mM}$, electrolyte: $0.1 \mathrm{M} \mathrm{NH}_{4} \mathrm{PF}_{6}$ in acetone/ $\mathrm{CH}_{3} \mathrm{CN} / \mathrm{H}_{2} \mathrm{O} 45: 45: 10 \mathrm{v} / \mathrm{v} / \mathrm{v} ; T=293 \mathrm{~K}$ ). All potentials taken in reference to the $\mathrm{Ag} / \mathrm{AgNO}_{3}$ reference electrode.

\section{Conclusions}

In summary, a novel redox-active ferrocene functionalised rotaxane with an all-halogen bonding cavity was synthesised. Anion binding studies in competitive aqueous media determined the rotaxane XB cavity was complementary towards spherical halides over other linear thiocyanate and tetrahedral sulfate anion geometries, with a distinct Hofmeister preference for binding the heavier, less strongly-hydrated halides. Electrochemical 
voltammetric anion sensing studies revealed that rotaxane 1 was capable of unprecedented selective $\mathrm{Br}^{-}$sensing over $\mathrm{Cl}^{-}$in the presence of water, as reflected in the relatively larger magnitude of cathodic perturbation of the XB rotaxane's ferrocene/ferrocenium redox couple. This valuable property highlights the potential of $\mathrm{XB}$ to complement $\mathrm{HB}$ in the selective recognition and sensing of biologically- and industrially-relevant anions under aqueous conditions.

\section{Experimental}

\section{General Information}

All commercially available chemicals and solvents were used as received without further purification. All dry solvents were thoroughly degassed with $\mathrm{N}_{2}$, dried through a Mbraun MPSP-800 column and used immediately. Water used was deionized and passed through a Milli- $Q^{\circledR}$ Millipore machine for microfiltration. TBTA (tris(benzyltriazolemethyl)amine) was prepared according to reported procedures. ${ }^{[46]}$ Chromatography was undertaken using silica gel (particle size: $40-63 \mu \mathrm{m}$ ) or preparative TLC plates $(20 \times 20 \mathrm{~cm}, 1 \mathrm{~mm}$ silica thickness).

NMR spectra were recorded on Bruker AVIII HD Nanobay 400 $\mathrm{MHz}$, Bruker AVIII $500 \mathrm{MHz}$ and Bruker AVIII $500 \mathrm{MHz}$ (with ${ }^{13} \mathrm{C}$ cryoprobe) spectrometers. Low resolution electrospray ionization mass spectrometry (ESI-MS) was performed using the Waters Micromass LCT for characterization of compounds previously reported in the literature, and high resolution ESI-MS was recorded using Bruker microTOF spectrometer for novel compounds. Electrochemical characterization of macrocycle $\mathbf{3 . I}$ and rotaxane 1 was performed by cyclic voltammetry (CV), while anion sensing studies were probed by square wave voltammetry (SWV) (full details in Section S4, Supporting Information). Spectra were recorded using an Autolab Potentiostat/Galvanostat model PG-STAT 12 (Metrohm Autolab, Netherlands), using a standard single compartment three-electrode electrochemical cell comprising a glassy carbon solid disc working electrode, platinum wire counter (auxiliary) electrode and a non-aqueous $\mathrm{Ag} / \mathrm{AgNO}_{3}$ reference electrode (prepared as described, ${ }^{[44]}$ placed inside a Faraday cage. For all experiments, $0.1 \mathrm{M} \mathrm{TBAPF}_{6}$ was present as supporting electrolyte.

\section{Synthetic procedures}

Compounds $\mathbf{5},{ }^{[47]} \mathbf{7},{ }^{[48]} \mathbf{8 . H},{ }^{[4]} \mathbf{8 . I},{ }^{[4]} \mathbf{9},{ }^{[49]} \mathbf{1 0} \mathbf{0}^{[50]}$ and $\mathbf{1 1 ^ { [ 5 1 ] }}$ were synthesized as reported.

\section{Ferrocene-appended bis(iodoalkyne) 4}

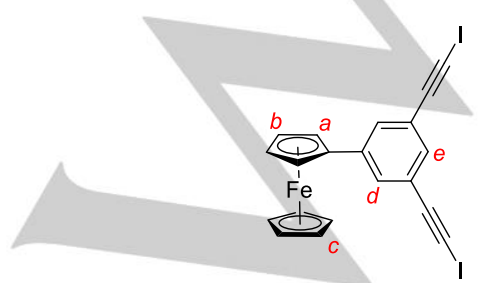

1-ferrocene-3,5-di(ethynyl)benzene (synthesized as reported ${ }^{[8]}$ ) $(210 \mathrm{mg}, 0.68 \mathrm{mmol})$ was dissolved in dry THF $(4 \mathrm{~mL})$ and chilled to $-78{ }^{\circ} \mathrm{C}$ in a dry ice/acetone bath. A $2.5 \mathrm{M}$ solution of $n$ - butyllithium ( $0.82 \mathrm{~mL}, 2.0 \mathrm{mmol}$ ) was added dropwise under $\mathrm{N}_{2}$ over 5 minutes and the reaction left to stir at $-78^{\circ} \mathrm{C}$ for 1 hour. In a separate vessel, molecular iodine $(518 \mathrm{mg}, 2.04 \mathrm{mmol})$ was dissolved in dry THF $(2 \mathrm{~mL})$ and added dropwise to the vigorously-stirred reaction, whereupon the reaction was left to gradually warm up to ambient temperature, and stirred for a further 2 hours. Following which, saturated aqueous sodium thiosulfate $(10 \mathrm{~mL})$ and chloroform $(20 \mathrm{~mL})$ was added to the reaction. The separated organic layer was washed successively with aqueous sodium thiosulfate $(10 \mathrm{~mL})$, water $(2 \times 10 \mathrm{~mL})$ and brine $(10 \mathrm{~mL})$ then dried with $\mathrm{MgSO}_{4}$. Purification by silica gel column chromatography ( $10 \%$ ethyl acetate in hexane) afforded the target compound as an orange solid (281 mg, $74 \%)$. ${ }^{1} \mathrm{H}-\mathrm{NMR}$ $\left(400 \mathrm{MHz}, \mathrm{CDCl}_{3}\right) \delta 7.47\left(2 \mathrm{H}, \mathrm{s}, \mathrm{H}_{\mathrm{d}}\right), 7.32\left(1 \mathrm{H}, \mathrm{s}, \mathrm{H}_{\mathrm{e}}\right), 4.64(2 \mathrm{H}$, $\left.\mathrm{m}, \mathrm{H}_{\mathrm{a}}\right), 4.36\left(2 \mathrm{H}, \mathrm{m}, \mathrm{H}_{\mathrm{b}}\right), 4.08\left(5 \mathrm{H}, \mathrm{s}, \mathrm{H}_{\mathrm{c}}\right) ;{ }^{13} \mathrm{C}-\mathrm{NMR}(100 \mathrm{MHz}$, $\left.\mathrm{CDCl}_{3}\right) \delta 140.3,133.2,129.8,123.6,93.3,82.9,69.8,69.6,66.5$, 7.3.

\section{Ferrocene-appended bis-phenol XB macrocycle precursor 6}

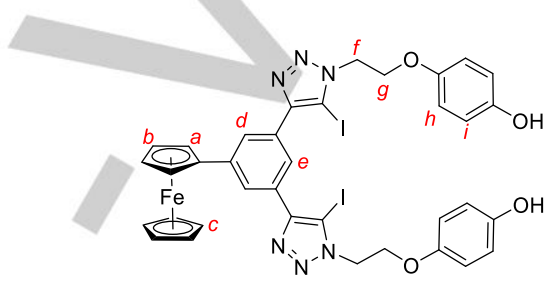

Azide 5 ( $90 \mathrm{mg}, 0.50 \mathrm{mmol}$ ) and bis-iodo(alkyne) 4 (135 mg, 0.240 $\mathrm{mmol})$ were dissolved in degassed THF $(3 \mathrm{~mL})$, followed by the portionwise addition of $\left[\mathrm{Cu}\left(\mathrm{CH}_{3} \mathrm{CN}\right)_{4}\right] \mathrm{PF}_{6}(45 \mathrm{mg}, 0.12 \mathrm{mmol})$ and TBTA (12 mg, $0.024 \mathrm{mmol}$ ). After stirring overnight, the crude mixture was partitioned between ethyl acetate $(20 \mathrm{~mL})$ and $1 \mathrm{M}$ aqueous ammonium chloride $(10 \mathrm{~mL})$. The separated organic layer was washed with saturated $\mathrm{Na}_{4}$ EDTA solution $(10 \mathrm{~mL})$ and the combined aqueous layer was back-extracted with ethyl acetate $(3 \times 10 \mathrm{~mL})$. The combined organics were dried with brine $(20 \mathrm{~mL})$ and $\mathrm{MgSO}_{4}$, dried on a rotary, and silica gel column chromatography (5\% methanol in dichloromethane) afforded the product as an orange solid (171 mg, $78 \%)$. ${ }^{1} \mathrm{H}-\mathrm{NMR}(400 \mathrm{MHz}$, $\left.\mathrm{CDCl}_{3}\right) \delta 8.48\left(1 \mathrm{H}, \mathrm{s}, \mathrm{H}_{\mathrm{e}}\right), 8.22\left(2 \mathrm{H}, \mathrm{s}, \mathrm{H}_{\mathrm{d}}\right), 7.91$ (br. s, OH), 6.83 $\left(4 \mathrm{H}, \mathrm{d},{ }^{3} \mathrm{~J}=8.8 \mathrm{~Hz}, \mathrm{H}_{\mathrm{h}}\right), 6.75\left(4 \mathrm{H}, \mathrm{d},{ }^{3} \mathrm{~J}=8.8 \mathrm{~Hz}, \mathrm{H}_{\mathrm{i}}\right), 4.93(4 \mathrm{H}, \mathrm{t}$, $\left.{ }^{3} \mathrm{~J}=5.2 \mathrm{~Hz}, \mathrm{H}_{\mathrm{f}}\right), 4.89\left(2 \mathrm{H}, \mathrm{s}, \mathrm{H}_{\mathrm{a}}\right), 4.52\left(4 \mathrm{H}, \mathrm{t},{ }^{3} \mathrm{~J}=5.4 \mathrm{~Hz}, \mathrm{H}_{\mathrm{g}}\right), 4.41$ $\left(2 \mathrm{H}, \mathrm{s}, \mathrm{H}_{\mathrm{b}}\right), 4.13\left(5 \mathrm{H}, \mathrm{s}, \mathrm{H}_{\mathrm{c}}\right) ;{ }^{13} \mathrm{C}-\mathrm{NMR}\left(100 \mathrm{MHz} \mathrm{CDCl}_{3}\right) \delta 152.8$, 152.6, 149.8, 141.3, 132.4, 125.5, 124.5, 116.8, 116.7, 85.5, 80.1, 70.6, 70.2, 68.0, 67.6, 51.0; HRMS (ESI +ve) $\mathrm{m} / \mathrm{z} 920.9841([\mathrm{M}+$ $\mathrm{H}]^{+}, \mathrm{C}_{36} \mathrm{H}_{31} \mathrm{~N}_{6} \mathrm{O}_{4}{ }^{56} \mathrm{Fe}^{127} I_{2}$, calc. 920.9840).

\section{Ferrocene-appended bis(iodotriazole) XB macrocycle 3.I}

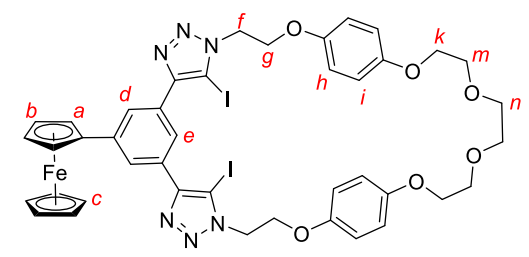

To a solution of compound $6(165 \mathrm{mg}, 0.179 \mathrm{mmol})$ and triethylene glycol-bistosylate $7(82 \mathrm{mg}, 0.179 \mathrm{mmol})$ in dry degassed DMF $(18 \mathrm{~mL})$ was added cesium carbonate $(292 \mathrm{mg}$, $0.895 \mathrm{mmol}$ ), and the reaction vigorously-stirred under $\mathrm{N}_{2}$ at 70 ${ }^{\circ} \mathrm{C}$ overnight. Thereafter, azeotropic removal of DMF on a rotary 
with toluene was followed by partitioning of the crude mixture between water $(20 \mathrm{~mL})$ and chloroform $(40 \mathrm{~mL})$. The aqueous layer was then back-extracted with chloroform $(3 \times 20 \mathrm{~mL})$ and the combined organics were dried with $\mathrm{MgSO}_{4}$. Solvent removal and purification by preparatory TLC (1.5\% methanol in dichloromethane) afforded the product as an orange powder (57 $\mathrm{mg}, 31 \%) .{ }^{1} \mathrm{H}-\mathrm{NMR}\left(400 \mathrm{MHz}, \mathrm{CDCl}_{3}\right) \delta 8.15\left(1 \mathrm{H}, \mathrm{s}, \mathrm{H}_{\mathrm{e}}\right), 8.04$ $\left(2 \mathrm{H}, \mathrm{s}, \mathrm{H}_{\mathrm{d}}\right), 6.79\left(4 \mathrm{H}, \mathrm{d},{ }^{3} \mathrm{~J}=9.2 \mathrm{~Hz}, \mathrm{H}_{\mathrm{h}}\right), 6.73\left(4 \mathrm{H}, \mathrm{d},{ }^{3} \mathrm{~J}=9.1 \mathrm{~Hz}\right.$, $\left.\mathrm{H}_{\mathrm{i}}\right), 4.88\left(4 \mathrm{H}, \mathrm{t},{ }^{3} \mathrm{~J}=4.7 \mathrm{~Hz}, \mathrm{H}_{\mathrm{f}}\right), 4.79\left(2 \mathrm{H}, \mathrm{s}, \mathrm{H}_{\mathrm{a}}\right), 4.44\left(4 \mathrm{H}, \mathrm{t},{ }^{3} \mathrm{~J}=\right.$ $\left.4.7 \mathrm{~Hz}, \mathrm{H}_{\mathrm{g}}\right), 4.36\left(2 \mathrm{H}, \mathrm{s}, \mathrm{H}_{\mathrm{b}}\right), 4.12\left(5 \mathrm{H}, \mathrm{s}, \mathrm{H}_{\mathrm{c}}\right), 4.03\left(4 \mathrm{H}, \mathrm{t},{ }^{3} \mathrm{~J}=4.7\right.$ $\left.\mathrm{Hz}, \mathrm{H}_{\mathrm{k}}\right), 3.78\left(4 \mathrm{H}, \mathrm{t},{ }^{3} \mathrm{~J}=4.7 \mathrm{~Hz}, \mathrm{H}_{\mathrm{m}}\right), 3.68\left(4 \mathrm{H}, \mathrm{s}, \mathrm{H}_{\mathrm{f}}\right) ;{ }^{13} \mathrm{C}-\mathrm{NMR}$ $\left(100 \mathrm{MHz}, \mathrm{CDCl}_{3}\right) \delta 153.5,152.2,149.9,140.5,130.6,125.6$, $124.5,115.7,115.6,84.4,78.7,70.8,69.7,69.6,69.2,68.2,67.5$, 66.8, 50.0; HRMS (ESI +ve) $\mathrm{m} / \mathrm{z} 1035.0525\left([\mathrm{M}+\mathrm{H}]^{+}\right.$, $\mathrm{C}_{42} \mathrm{H}_{41} \mathrm{~N}_{6} \mathrm{O}_{6}{ }^{56} \mathrm{Fe}^{127} I_{2}$, calc. 1035.0521).

\section{Neutral Ferrocene-appended All-XB Rotaxane 2.I}

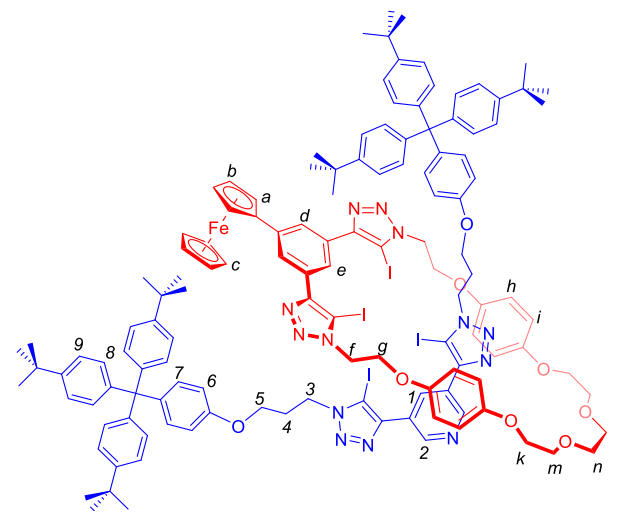

Approach 1: Macrocycle 3.1 (20 mg, $0.019 \mathrm{mmol})$, pyridine-3,5bis(iodoalkyne) 8 (29 mg, $0.077 \mathrm{mmol}$ ), stopper azide 9 (90 mg, $0.154 \mathrm{mmol})$ and $\left[\mathrm{Cu}\left(\mathrm{CH}_{3} \mathrm{CN}\right)_{4}\right] \mathrm{PF}_{6}(7.2 \mathrm{mg}, 0.019 \mathrm{mmol})$ were mixed in a two-neck round-bottom flask and thoroughly degassed by three cycles of evacuation and refilling with $\mathrm{N}_{2}$. Thoroughlydegassed dry dichloromethane $(2 \mathrm{~mL})$ was then added and the resulting solution left to stir till complete consumption of axle precursors was observed (7 days) by TLC analysis (eluent: $5 \%$ methanol in dichloromethane). The reaction was then diluted with chloroform $(20 \mathrm{~mL})$ and washed with basic aqueous EDTA solution $(2 \times 10 \mathrm{~mL})$ then dried with $\mathrm{MgSO}_{4}$. Purification by preparatory TLC (2.5\% methanol in dichloromethane) yielded the target rotaxane as a light orange powder (16 mg, $31 \%)$.

Approach 2: Macrocycle 3.1 ( $22 \mathrm{mg}, 0.021 \mathrm{mmol}$ ), half-axle 10 (82 $\mathrm{mg}, 0.084 \mathrm{mmol})$, stopper azide $9(50 \mathrm{mg}, 0.084 \mathrm{mmol})$ and $\left[\mathrm{Cu}\left(\mathrm{CH}_{3} \mathrm{CN}\right)_{4}\right] \mathrm{PF}_{6}(7.8 \mathrm{mg}, 0.021 \mathrm{mmol})$ were mixed in a two-neck round-bottom flask and thoroughly degassed by three cycles of evacuation and refilling with $\mathrm{N}_{2}$. Thoroughly-degassed dry dichloromethane $(2 \mathrm{~mL}$ ) was then added and the resulting solution left to stir for three days, whereupon TLC analysis (eluent: $5 \%$ methanol in dichloromethane) showed complete consumption of axle precursors. Aqueous work-up and purification was performed as described for Approach 1 to yield the pure rotaxane $(18 \mathrm{mg}$, $33 \%)$.

${ }^{1} \mathrm{H}-N M R\left(500 \mathrm{MHz}, \mathrm{CDCl}_{3}\right) \delta 9.20\left(2 \mathrm{H}, \mathrm{s}, \mathrm{H}_{2}\right), 8.78\left(1 \mathrm{H}, \mathrm{s}, \mathrm{H}_{1}\right)$, $8.27\left(1 \mathrm{H}, \mathrm{t},{ }^{4} \mathrm{~J}=1.5 \mathrm{~Hz}, \mathrm{H}_{\mathrm{e}}\right), 8.03\left(2 \mathrm{H}, \mathrm{d},{ }^{4} \mathrm{~J}=1.5 \mathrm{~Hz}, \mathrm{H}_{\mathrm{d}}\right), 7.22$ $7.24\left(12 \mathrm{H}, \mathrm{m}, \mathrm{H}_{8}\right), 7.08-7.11\left(16 \mathrm{H}, \mathrm{m}, \mathrm{H}_{9}+\mathrm{H}_{7}\right), 6.65\left(4 \mathrm{H}, \mathrm{d},{ }^{3} \mathrm{~J}=\right.$ $\left.8.5 \mathrm{~Hz}, \mathrm{H}_{6}\right), 6.44\left(4 \mathrm{H}, \mathrm{d},{ }^{3} \mathrm{~J}=8.9 \mathrm{~Hz}, \mathrm{H}_{\mathrm{h}}\right), 6.37\left(4 \mathrm{H}, \mathrm{d},{ }^{3} \mathrm{~J}=8.9 \mathrm{~Hz}\right.$, $\left.\mathrm{H}_{\mathrm{i}}\right), 4.82\left(4 \mathrm{H}, \mathrm{t},{ }^{3} \mathrm{~J}=4.7 \mathrm{~Hz}, \mathrm{H}_{\mathrm{f}}\right), 4.74\left(2 \mathrm{H}, \mathrm{t},{ }^{3} \mathrm{~J}=1.8 \mathrm{~Hz}, \mathrm{H}_{\mathrm{a}}\right), 4.32$ $\left(2 \mathrm{H}, \mathrm{t},{ }^{3} \mathrm{~J}=1.8 \mathrm{~Hz}, \mathrm{H}_{\mathrm{b}}\right), 4.22\left(4 \mathrm{H}, \mathrm{t},{ }^{3} \mathrm{~J}=4.7 \mathrm{~Hz}, \mathrm{H}_{\mathrm{g}}\right), 4.18(4 \mathrm{H}, \mathrm{t}$, $\left.{ }^{3} J=6.0 \mathrm{~Hz}, \mathrm{H}_{3}\right), 4.07\left(5 \mathrm{H}, \mathrm{s}, \mathrm{H}_{\mathrm{c}}\right), 3.91\left(4 \mathrm{H}, \mathrm{t},{ }^{3} \mathrm{~J}=4.3 \mathrm{~Hz}, \mathrm{H}_{5}\right)$, 3.71-3.75 $\left(8 \mathrm{H}, \mathrm{m}, \mathrm{H}_{\mathrm{k}}+\mathrm{H}_{\mathrm{m}}\right), 3.67\left(4 \mathrm{H}, \mathrm{s}, \mathrm{H}_{\mathrm{n}}\right), 2.05\left(4 \mathrm{H}, \mathrm{m}, \mathrm{H}_{4}\right)$, $1.31\left(54 \mathrm{H}\right.$, stopper-t'Bu); ${ }^{13} \mathrm{C}-\mathrm{NMR}\left(125 \mathrm{MHz}, \mathrm{CDCl}_{3}\right) \delta 156.2$ 153.0, 151.7, 149.8, 148.3, 147.8, 146.4, 144.2, 144.0, 140.5, $139.8,132.2,131.8,130.7,126.2,125.6,124.8,124.1,115.0$, $114.9,113.1,84.4,70.9,69.8,69.7,69.5,69.2,67.4,66.8,64.0$, 63.1, 53.8, 50.1, 47.9, 34.3, 31.4, 29.3; HRMS (ESI +ve) $\mathrm{m} / \mathrm{z}$ $2588.6719\left([\mathrm{M}+\mathrm{H}]^{+}, \mathrm{C}_{131} \mathrm{H}_{142} \mathrm{~N}_{13} \mathrm{O}_{8}{ }^{127} \mathrm{l}_{4}{ }^{56} \mathrm{Fe}\right.$, calc. 2588.6627).

\section{Cationic Ferrocene-appended Target Rotaxane 1}

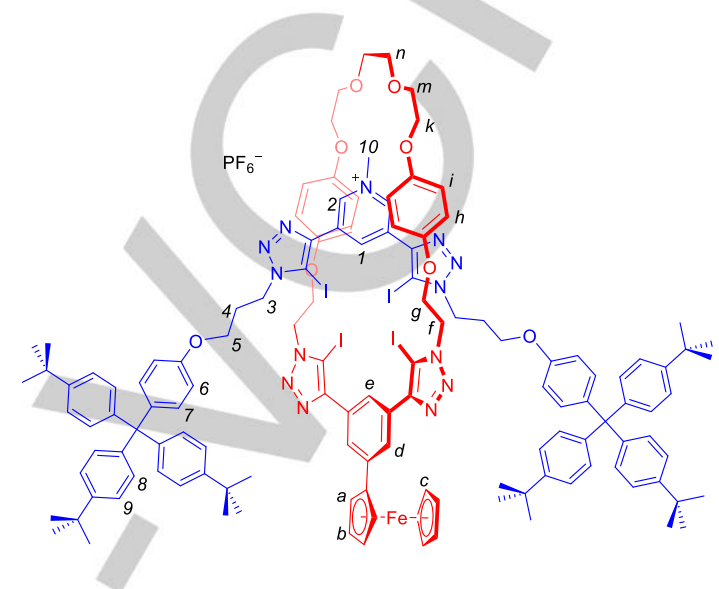

To a solution of neutral rotaxane 2.1 (20 mg, $7.7 \mu \mathrm{mol})$ in dry dichloromethane $(0.5 \mathrm{~mL})$ was added iodomethane $(0.1 \mathrm{~mL})$ and the reaction stirred overnight at room temperature. Removal of solvent in vacuo followed by purification by preparatory TLC (eluent: $4 \%$ methanol in dichloromethane) afforded the product as an orange solid. Anion exchange was performed by dissolving the rotaxane in chloroform $(20 \mathrm{~mL})$ and repeated washing with 0.1 $\mathrm{M} \mathrm{NH}_{4} \mathrm{PF}_{6}$ (aq.) $(8 \times 10 \mathrm{~mL})$ followed by water $(2 \times 10 \mathrm{~mL})$. The organic phase was dried with $\mathrm{MgSO}_{4}$ and solvent removed to afford the $\mathrm{PF}_{6}-$ salt of target rotaxane $\mathbf{1}$ as a light orange solid (16 $\mathrm{mg}, 76 \%)$.

${ }^{1} \mathrm{H}-\mathrm{NMR}\left(500 \mathrm{MHz}, \mathrm{CDCl}_{3}\right) \delta 9.31\left(2 \mathrm{H}, \mathrm{s}, \mathrm{H}_{2}\right), 8.76\left(1 \mathrm{H}, \mathrm{s}, \mathrm{H}_{1}\right)$, $8.34\left(1 \mathrm{H}, \mathrm{s}, \mathrm{H}_{\mathrm{e}}\right), 8.06\left(2 \mathrm{H}, \mathrm{s}, \mathrm{H}_{\mathrm{d}}\right), 7.22\left(12 \mathrm{H}, \mathrm{d},{ }^{3} \mathrm{~J}=8.6 \mathrm{~Hz}, \mathrm{H}_{8}\right)$, $7.11\left(4 \mathrm{H}, \mathrm{d},{ }^{3} \mathrm{~J}=8.9 \mathrm{~Hz}, \mathrm{H}_{7}\right), 7.08\left(12 \mathrm{H}, \mathrm{d},{ }^{3} J=8.6 \mathrm{~Hz}, \mathrm{H}_{9}\right), 6.78$ $\left(4 \mathrm{H}, \mathrm{d},{ }^{3} \mathrm{~J}=8.7 \mathrm{~Hz}, \mathrm{H}_{6}\right), 6.19\left(4 \mathrm{H}, \mathrm{d},{ }^{3} J=9.0 \mathrm{~Hz}, \mathrm{H}_{\mathrm{h}}\right), 6.07(4 \mathrm{H}, \mathrm{d}$, $\left.{ }^{3} J=9.0 \mathrm{~Hz}, \mathrm{H}_{\mathrm{i}}\right), 4.77-4.79\left(6 \mathrm{H}, \mathrm{m}, \mathrm{H}_{\mathrm{a}}+\mathrm{H}_{\mathrm{f}}\right), 4.70\left(3 \mathrm{H}, \mathrm{s}, \mathrm{H}_{10}\right), 4.36$ $\left(4 \mathrm{H}, \mathrm{t},{ }^{3} \mathrm{~J}=6.1 \mathrm{~Hz}, \mathrm{H}_{3}\right), 4.31\left(2 \mathrm{H}, \mathrm{s}, \mathrm{H}_{\mathrm{b}}\right), 4.07-4.09\left(9 \mathrm{H}, \mathrm{m}, \mathrm{H}_{\mathrm{c}}+\right.$ $\left.\mathrm{H}_{\mathrm{g}}\right), 3.93\left(4 \mathrm{H}, \mathrm{t},{ }^{3} \mathrm{~J}=5.6 \mathrm{~Hz}, \mathrm{H}_{5}\right), 3.76-3.81\left(12 \mathrm{H}, \mathrm{m}, \mathrm{H}_{\mathrm{K}}+\mathrm{H}_{\mathrm{m}}+\right.$ $\left.\mathrm{H}_{\mathrm{n}}\right), 2.27\left(4 \mathrm{H}\right.$, quint., $\left.{ }^{3} \mathrm{~J}=6.0 \mathrm{~Hz}, \mathrm{H}_{4}\right), 1.30\left(54 \mathrm{H}\right.$, stopper- $\left.{ }^{\mathrm{t}} \mathrm{Bu}\right)$; ${ }^{13}$ C-NMR $\left(125 \mathrm{MHz}, \mathrm{CDCl}_{3}\right) \delta 156.3,152.4,151.7,149.8,148.3$, $144.1,141.9,141.4,141.0,140.0,133.7,132.3,130.9,130.8$, 130.7, 125.3, 124.1, 114.8, 114.2, 113.1, 84.1, 70.9, 70.2, 69.7, 69.4, 67.2, 66.8, 63.8, 63.1, 53.7, 50.1, 49.2, 48.1, 34.3, 31.4, 29.7; ${ }^{19} \mathrm{~F}-\mathrm{NMR}\left(376 \mathrm{MHz}, \mathrm{CDCl}_{3}\right) \delta-72.8\left(\mathrm{~d},{ }^{1} \mathrm{~J}_{\mathrm{F}-\mathrm{P}}=720 \mathrm{~Hz}\right) ;{ }^{31} \mathrm{P}-$ NMR (162 MHz, $\left.\mathrm{CDCl}_{3}\right) \delta-144.4$ (sep., ${ }^{1} \mathrm{JP}_{\mathrm{P}-\mathrm{F}}=720 \mathrm{~Hz}$ ); HRMS $(\mathrm{ESI}+\mathrm{ve}) \mathrm{m} / \mathrm{z} 2602.6733\left([\mathrm{M}]^{+},\left.\mathrm{C}_{132} \mathrm{H}_{144} \mathrm{~N}_{13} \mathrm{O}_{8}{ }^{127}\right|_{4}{ }^{56} \mathrm{Fe}\right.$, calc. 2602.6784).

\section{Acknowledgments}

J.Y.C.L acknowledges the Agency for Science, Technology and Research $\left(A^{*} S T A R\right)$ for postgraduate research funding.

Keywords: halogen bonding $\cdot$ rotaxane $\cdot$ electrochemical $\bullet$ anion sensing $\bullet$ bromide 
[1] R. S. Magazinovic, B. C. Nicholson, D. E. Mulcahy, D. E. Davey, Chemosphere 2004, 57, 329-335.

[2] L. Puljak, G. Kilic, Biochim. Biophys. Acta BBA - Mol. Basis Dis. 2006 1762, 404-413.

[3] T. J. Jentsch, V. Stein, F. Weinreich, A. A. Zdebik, Physiol. Rev. 2002, 82, 503-568.

[4] E. Argenzio, W. H. Moolenaar, J. Cell Sci. 2016, 129, 4165-4174.

[5] O. Dohán, A. De la Vieja, V. Paroder, C. Riedel, M. Artani, M. Reed, C. S. Ginter, N. Carrasco, Endocr. Rev. 2003, 24, 48-77.

6] M. B. Zimmermann, Semin. Cell Dev. Biol. 2011, 22, 645-652.

[7] A. S. McCall, C. F. Cummings, G. Bhave, R. Vanacore, A. Page-McCaw, B. G. Hudson, Cell 2014, 157, 1380-1392.

[8] F. X. R. van Leeuwen, B. Sangster, A. G. Hildebrandt, CRC Crit. Rev. Toxicol. 1987, 18, 189-213.

[9] M. Disse, F. Joo, H. Schulz, J. R. Wolff, J Himforsch 1996, 37, 127-134.

[10] S. Cheng, X. Zhang, X. Yang, C. Shang, W. Song, J. Fang, Y. Pan, Environ. Sci. Technol. 2018, 52, 1806-1816.

[11] Y. Yang, Y. Komaki, S. Y. Kimura, H.-Y. Hu, E. D. Wagner, B. J. Mariñas, M. J. Plewa, Environ. Sci. Technol. 2014, 48, 12362-12369.

[12] P. A. Gale, C. Caltagirone, Chem Soc Rev 2015, 44, 4212-4227.

[13] P. A. Gale, E. N. W. Howe, X. Wu, Chem n.d., 1, 351-422.

[14] P. Molina, F. Zapata, A. Caballero, Chem. Rev. 2017, 117, 9907-9972.

[15] R. M. Duke, E. B. Veale, F. M. Pfeffer, P. E. Kruger, T. Gunnlaugsson, Chem Soc Rev 2010, 39, 3936-3953.

[16] R. Sakai, Polym. J. 2015, 48, 59.

[17] Y. Marcus, J Chem Soc Faraday Trans 1991, 87, 2995-2999.

[18] C. Suksai, P. Leeladee, D. Jainuknan, T. Tuntulani, N. Muangsin, O. Chailapakul, P. Kongsaeree, C. Pakavatchai, Tetrahedron Lett. 2005 46. 2765-2769.

[19] J. Kang, J. Kim, Tetrahedron Lett. 2005, 46, 1759-1762.

[20] D. Vlascici, N. Plesu, G. Fagadar-Cosma, A. Lascu, M. Petric, M. Crisan A. Belean, E. Fagadar-Cosma, Sensors 2018, 18, 2297

[21] P. D. Beer, P. A. Gale, G. Z. Chen, J Chem Soc Dalton Trans 1999 , 1897-1910.

[22] F. Zapata, A. Caballero, A. Tárraga, P. Molina, J. Org. Chem. 2010, 75, 162-169.

[23] P. Molina, A. Tárraga, M. Alfonso, Dalton Trans. 2014, 43, 18-29.

[24] R. Sun, L. Wang, H. Yu, Z.- Abdin, Y. Chen, J. Huang, R. Tong, Organometallics 2014, 33, 4560-4573.

[25] N. H. Evans, P. D. Beer, Org Biomol Chem 2011, 9, 92-100

[26] N. H. Evans, H. Rahman, A. V. Leontiev, N. D. Greenham, G. A. Orlowski, Q. Zeng, R. M. J. Jacobs, C. J. Serpell, N. L. Kilah, J. J. Davis, et al., Chem Sci 2012, 3, 1080-1089.

[27] N. H. Evans, C. J. Serpell, P. D. Beer, Chem Commun 2011, 47, 87758777.

[28] N. H. Evans, C. J. Serpell, N. G. White, P. D. Beer, Chem. - Eur. J. 2011, 17, 12347-12354

[29] J. Y. C. Lim, M. J. Cunningham, J. J. Davis, P. D. Beer, Dalton Trans 2014, 43, 17274-17282.
[30] The lower oxidation potential of iodide compared with ferrocene precludes the use of ferrocene-containing host molecules from iodide sensing.

[31] G. Cavallo, P. Metrangolo, R. Milani, T. Pilati, A. Priimagi, G. Resnati, G. Terraneo, Chem. Rev. 2016, 116, 2478-2601.

[32] T. M. Beale, M. G. Chudzinski, M. G. Sarwar, M. S. Taylor, Chem Soc Rev 2013, 42, 1667-1680.

[33] A. Brown, P. D. Beer, Chem Commun 2016, 52, 8645-8658.

[34] A.-C. C. Carlsson, A. X. Veiga, M. Erdélyi, in Halog. Bond. II Impact Mater. Chem. Life Sci. (Eds.: P. Metrangolo, G. Resnati), Springer International Publishing, Cham, 2015, pp. 49-76.

[35] S. W. Robinson, C. L. Mustoe, N. G. White, A. Brown, A. L. Thompson, P. Kennepohl, P. D. Beer, J. Am. Chem. Soc. 2015, 137, 499-507.

[36] J. Y. C. Lim, M. J. Cunningham, J. J. Davis, P. D. Beer, Chem Commun 2015, 51, 14640-14643.

[37] J. Y. C. Lim, P. D. Beer, Eur. J. Inorg. Chem. 2017, 2017, 220-224.

[38] R. Oliveira, S. Groni, C. Fave, M. Branca, F. Mavre, D. Lorcy, M. Fourmigue, B. Schollhorn, Phys Chem Chem Phys 2016, 18, 1586715873.

[39] J. D. Crowley, S. M. Goldup, A.-L. Lee, D. A. Leigh, R. T. McBurney, Chem Soc Rev 2009, 38, 1530-1541.

[40] M. Denis, S. M. Goldup, Nat. Rev. Chem. 2017, 1, 0061.

[41] J. Y. C. Lim, T. Bunchuay, P. D. Beer, Chem. - Eur. J. 2017, 23, 47004707.

[42] M. J. Hynes, J. Chem. Soc. Dalton Trans. 1993, 311-312.

[43] While $\mathrm{CH}_{3} \mathrm{CN}$ ensured solvent compatibility with the non-aqueous $\mathrm{Ag}$ $\mathrm{AgNO}_{3}$ reference electrode, acetone was necessary to ensure rotaxane solubility.

[44] B. Kratochvil, E. Lorah, C. Garber, Anal. Chem. 1969, 41, 1793-1796.

[45] The possibility that the shifts in redox potential were due to increasing dilution upon addition of anions could be ruled out from a contro experiment, where no changes in $E_{1 / 2}$ of rotaxane 1 in acetone/ $\mathrm{CH}_{3} \mathrm{CN}$ $\mathrm{H}_{2} \mathrm{O} 45: 45: 10 \mathrm{~V} / \mathrm{V} / \mathrm{V}$ were observed upon dilution of the rotaxane solution from $0.10 \mathrm{mM}$ to $0.033 \mathrm{mM}$ (see Figure S4-8, Supporting Information) B.-Y. Lee, S. R. Park, H. B. Jeon, K. S. Kim, Tetrahedron Lett. 2006 47, 5105-5109.

[47] J. Y. C. Lim, I. Marques, A. L. Thompson, K. E. Christensen, V. Félix P. D. Beer, J. Am. Chem. Soc. 2017, 139, 3122-3133.

[48] T. Ai, L. Qiu, J. Xie, R. J. Geraghty, L. Chen, Bioorg. Med. Chem. 2016 $24,686-692$

[49] V. Aucagne, K. D. Hänni, D. A. Leigh, P. J. Lusby, D. B. Walker, J. Am Chem. Soc. 2006, 128, 2186-2187.

[50] J. Y. C. Lim, I. Marques, V. Félix, P. D. Beer, Angew. Chem. Int. Ed. 2018, 57, 584-588; J. Y. C. Lim, I. Marques, V. Félix, P. D. Beer, Angew. Chem., 2018, 130, 593-597.

[51] J. Y. C. Lim, P. D. Beer, Chem. Commun. 2015, 51, 3686-3688. 
Entry for the Table of Contents (Please choose one layout)

Layout 1:

\section{FULL PAPER}

The unprecedented use of a redox active ferrocene appended halogen bonding [2]rotaxane to selectively sense bromide electrochemically in aqueous-organic solvent mixtures has been achieved.

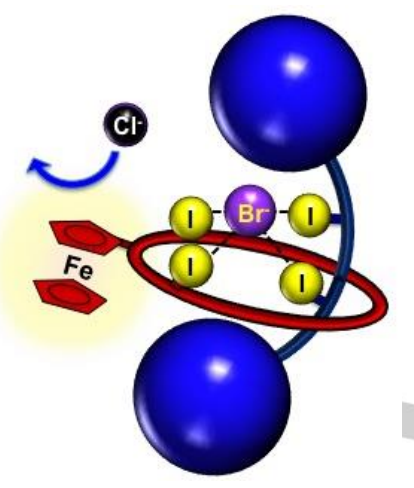

Anion Sensing *

Jason Y. C. Lim, Paul D. Beer*

Page No. - Page No.

Electrochemical Bromide Sensing with a Halogen Bonding [2]Rotaxane

*one or two words that highlight the emphasis of the paper or the field of the study

\section{Layout 2:}

\section{FULL PAPER}

((Insert TOC Graphic here; max. width: $11.5 \mathrm{~cm}$; max. height: $2.5 \mathrm{~cm}$; NOTE: the final letter height should not be less than $2 \mathrm{~mm}$.))

Text for Table of Contents (about 350 characters)

*one or two words that highlight the emphasis of the paper or the field of the study

\section{Key Topic*}

Author(s), Corresponding Author(s)*

Page No. - Page No.

Title 